\title{
Implementasi Algoritma Dijkstra untuk Pencarian Rute Terpendek Menuju Rumah Sakit pada Aplikasi C-Hos (Covid-19 Hospital)
}

\author{
Muhammad Taufiq Ismail*, Septi Andryana, Aris Gunaryati \\ Fakultas Teknologi Komunikasi dan Informatika, Prodi Informatika, Universitas Nasional, Jakarta Selatan, Indonesia \\ Email: ${ }^{1,{ }^{*}}$ taufiqm370@gmail.com, ${ }^{2}$ septi.andryana@ civitas.unas.ac.id, ${ }^{3}$ arisgunaryati@ civitas.unas.ac.id \\ Email Penulis Korespondensi: taufiqm370@gmail.com
}

\begin{abstract}
Abstrak-Tepat pada tanggal 2 Maret 2020 corona virus (Covid-19) masuk ke Indonesia. Di Jakarta sudah terdapat 445.302 kasus positif Covid-19 per tanggal 12 Juni 2021. Pemerintah sendiri telah menunjuk wisma atlet sebagai rumah sakit darurat corona dan juga terdapat beberapa rumah sakit di Jakarta untuk menjadi rumah sakit rujukan Covid-19. Akan tetapi banyak masyarakat yang belum mengetahui rumah sakit rujukan covid-19. Hal ini sangat disayangkan, karena jika sewaktu-waktu masyarakat atau warga yang sudah menunjukan gejala covid-19 bisa langsung datang ke rumah sakit rujukan Covid-19 terdekat. Dari permasalah tersebut, maka dibuatlah aplikasi C-Hos (Covid-19 Hospital) berbasis android dengan menerapkan Algoritma Dijkstra untuk pencarian rute terpendek menuju rumah sakit rujukan Covid-19. Berdasarkan hasil pengujian sebanyak 20 kali maka mendapatkan akurasi ketepatan rute terpendek menuju rumah sakit rujukan Covid-19 pada aplikasi CHos sebesar $100 \%$.
\end{abstract}

Kata Kunci: Rumah Sakit Rujukan Covid-19; Algoritma Dijkstra; Rute Terpendek; Covid-19; C-Hos

\begin{abstract}
Exactly on March 2, 2020, the corona virus (Covid-19) entered Indonesia. In Jakarta, there were 445,302 positive cases of Covid-19 as of June 12, 2021. The government itself has appointed Wisma Athletes as an emergency corona hospital and there are also several hospitals in Jakarta to serve as COVID-19 referral hospitals However, many people do not know the referral hospital for COVID-19. This is very unfortunate, because at any time people or residents who have shown symptoms of Covid-19 can immediately come to the nearest Covid-19 referral hospital. From this problem, an Android-based C-Hos (Covid-19 Hospital) application was created by applying the Dijkstra Algorithm to search for the shortest route to the covid19 referral hospital. Based on the results of testing 20 times, the accuracy of the shortest route to the Covid-19 referral hospital on the C-Hos application is $100 \%$.
\end{abstract}

Keywords: Covid-19 Hospital; Dijkstra's Algorithm; Shortest Route; Covid-19; C-Hos

\section{PENDAHULUAN}

Virus corona dilaporkan pertama kali di Tiongkok tepatnya dikota Wuhan pada tanggal 31 Desember 2019[1]. Di Indonesia per tanggal 2 Maret 2020 masuk ke dalam negara yang terjangkit Covid-19. Sampai tanggal 12 juni 2021 terdapat 1.901 .490 yang terkonfirmasi positif Covid-19 di Indonesia, sedangkan di Jakarta terdapat 445.302 kasus positif Covid-19 per tanggal 12 juni 2021. Dalam kasus Covid-19 ini, pemerintah dengan sigapnya menunjuk wisma atlet dan beberapa rumah sakit di Jakarta sebagai rumah sakit rujukan Covid-19. Namun permasalahannya banyak masyarakat yang kurang mengetahui rumah sakit mana yang menjadi rujukan Covid-19.

Oleh karena itu, dari pemasalahan tersebut penulis menawarkan solusi dengan membuat aplikasi C-Hos (Covid-19 Hospital) berbasis android dengan menerapkan Algoritma Dijkstra untuk mencari rute terpendek menuju rumah sakit rujukan Covid-19, tetapi aplikasi C-Hos ini untuk lokasi awalnya sudah ditentukan terlebih dahulu titik kordinatnya, ada dua lokasi awal yaitu rumah dan kantor. Algoritma Dijkstra sendiri merupakan algoritma pencarian graf yang bertujuan untuk mencari jalur terpendek dari satu simpul ke simpul lainnya dengan bobot simpul tidak boleh negatif[2].

Banyak penelitian sebelumnya yang membahas Algoritma Dijkstra untuk menetukan rute terpendek, yaitu penelitian yang dilakukan oleh Raharjo, M. I. \& Susilawati, I. tentang pencarian rute terpendek untuk wisata kota Yogyakarta yang menerapkan Algoritma Dijkstra dengan menghasilkan akurasi sebesar 60\%[3].

Berikutnya peneletian serupa juga dilakukan Setiawan, J., Prakoso, R. S., \& Suryaningrum, K. M. dalam menentukan rute terpendek menuju pusat perbelanjaan di Jakarta yang bermaksud untuk mempermudah masyarakat Jakarta maupun luar Jakarta yang ingin berkunjung ke pusat perbelanjaan[4].

Penelitian berikutnya yang dilakukan ole Sauwani, Jeki, Vitcky Nanda Putra, dan Halim Agung yang bertujuan untuk memudahkan calon mahasiswa atau mahasiswi dalam mencari perguruan tinggi IT di Jakarta dengan menerapankan Algoritma Dijkstra yang menghasilkan akurasi ketepatan rute sebesar $75 \%$ [5].

Penelitian yang dilakukan Yusuf, Muhammad Syamsuddin, Hanifah Muslimah Az-Zahra, dan Diah Harnoni Apriyanti yang berfokus pada penentuan jalur terpendek dari lokasi user ke tanaman yang di tuju. Metode yang digunakan pada penelitian ini ialah metode tahapan yang terdiri dari studi literatur hingga pengambilan keputusan.[6].

Dari penelitian sebelumnya yang sudah ada, maka penulis menawarkan solusi dengan merancang aplikasi C-Hos (Covid-19 Hospital) berbasis android dengan menerapkan Algoritma Dijkstra yang bertujuan untuk memberi informasi terkait rumah sakit mana saja yang menjadi rujukan Covid-19 dan untuk memudahkan masyarakat dalam pencarian rute terpendek menuju rumah sakit rujukan Covid-19. 


\section{METODOLOGI PENELITIAN}

Metode yang digunakan ialah tahapan atau langkah-langkah untuk menyelesaikan penelitian ini. Berikut flowchart tahapan penelitian bisa diliat pada gambar 1 .

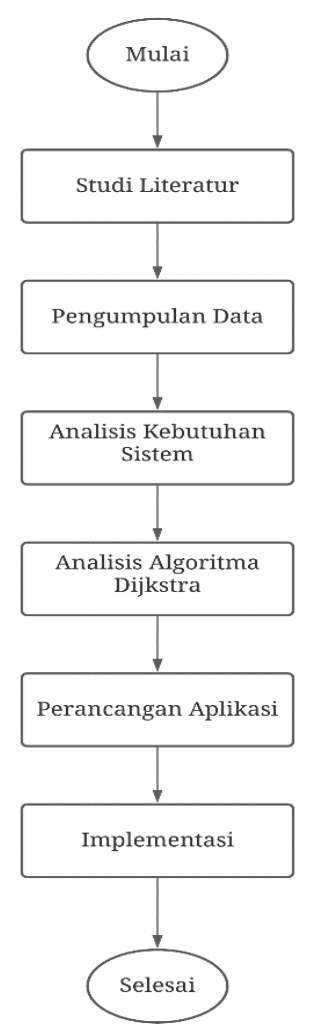

Gambar 1. Flowchart Tahapan Penelitian

\subsection{Studi Literatur}

Tahap pertama adalah studi literatur yang merupakan tahap pengumpulan sejumlah buku, jurnal dan penulisan ilmiah yang berkaitan dengan penelitian.

\subsection{Pengumpulan Data}

Yang kedua ialah tahap pengumpulan data. Dimana pengumpulan data itu sendiri dalam penelitian ini berasal dari web resmi Covid-19 (https://covid19.go.id/) dan Google Maps.

\subsection{Analisis Kebutuhan Sistem}

Pada perancangan aplikasi rumah sakit rujukan Covid-19 ini memerlukan perangkat penunjang seperti:

a. Perangkat keras (Hardware): Laptop (Acer) dengan spesifikasi sebagai berikut Processor AMD Ryzen 5 2500U, RAM 8GB, Harddisk 320GB, SSD 240GB dan Grafik AMD Radeon Vega 8.

b. Perangkat lunak (Software): OS Windows 10 pro 64bit dan Android Studio 3.6.

\subsection{Algoritma Dijkstra}

Pada penilitian ini penulis menerapkan metode Algoritma Dijkstra untuk menentukan rute terpendek. Algoritma Dijkstra ialah algoritma yang bermaksud untuk mencari jalur terpendek pada sebuah graf. Prinsip dari Algoritma Dijkstra ialah pencarian dua lintasan yang memiliki bobot terkecil[7].

Analisis pencarian rute terpendek menuju rumah sakit rujukan Covid-19 dengan menggunakan Algoritma Dijkstra:

a. Menentukan node-node yang ada.

b. Membuat graf antar node-node yang sudah ditentukan sebelumnya.

c. Setelah itu menghitung nilai antar jarak dari satu node ke node lainnya.

\subsection{Tahap Perancangan Aplikasi}

Pada tahap ini, ada beberapa tahap mulai dari merancang splash screen, tampilan awal, menu rumah sakit rujukan Covid-19, informasi rumah sakit rujukan Covid-19 dan maps yang menampilkan rute terpendek menuju rumah sakit. Berikut flowchart tahapan perancangan aplikasi bisa dilihat pada gambar 2. 
ISSN 2614-5278 (media cetak), ISSN 2548-8368 (media online)

Available Online at https://ejurnal.stmik-budidarma.ac.id/index.php/mib DOI 10.30865/mib.v5i3.3077

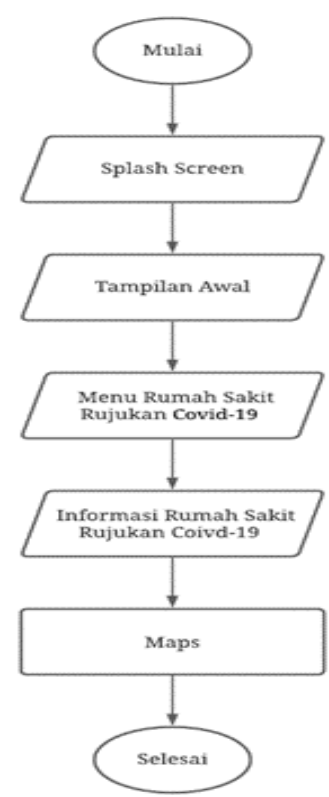

Gambar 2. Flowchart Perancangan Aplikasi

\section{HASIL DAN PEMBAHASAN}

Pada analisis algoritma dijkstra ini penulis mengambil contoh kasus pencarian rute terpendek dari rumah menuju lokasi RSUD Ciracas. Berikut data nama jalan yang dilalui, node dan jarak antar node-node dari rumah menuju RSUD Ciracas bisa dilihat pada tabel 1.

Tabel 1. Nama Jalan, Node dan Jarak antar Node

\begin{tabular}{llll}
\hline No & \multicolumn{1}{c}{ Nama Jalan } & \multicolumn{1}{c}{ Node } & \multicolumn{1}{c}{ Jarak } \\
\hline 1 & Jl. Sd inpres - Jl Mujahidin & A - B & $0.45 \mathrm{~km}$ \\
2 & Jl. Sd inpres - Jl. TB Simatupang & A - D & $0.50 \mathrm{~km}$ \\
3 & Jl. Mujahidin - Jl. Tanah Merdeka & B - C & $0.3 \mathrm{~km}$ \\
4 & Jl. Tanah Merdeka - Jl. Raya Bogor & C - E & $0.55 \mathrm{~km}$ \\
5 & Jl. TB Simatupang - Jl. Raya Bogor & D - F & $3.8 \mathrm{~km}$ \\
6 & Jl. TB Simatupang- Jl. Gempol Raya & D - G & $2.9 \mathrm{~km}$ \\
7 & Jl. Raya Bogor - Jl. Raya Bogor & E - F & $0.5 \mathrm{~km}$ \\
8 & Jl. Raya bogor - Jl. Kiwi & F - L & $3.7 \mathrm{~km}$ \\
9 & Jl. Gempol Raya - Mcd Cipayung & G - H & $3 \mathrm{~km}$ \\
10 & Jl. Cipayung Raya - Jl. Raya Klp. Wetan & H - I & $0.1 \mathrm{~km}$ \\
11 & Jl. Raya Klp. Wetan - Jl. Raya PKP & I - J & $1.1 \mathrm{~km}$ \\
12 & Jl. Raya PKP - Jl. Cibubur 1 & J - K & $1.5 \mathrm{~km}$ \\
13 & Jl. Cibubur 1 - RSUD Ciracas & K - M & $0.6 \mathrm{~km}$ \\
14 & Jl. Kiwi - Jl. Cibubur 1 & L - K & $0.7 \mathrm{~km}$ \\
\hline
\end{tabular}

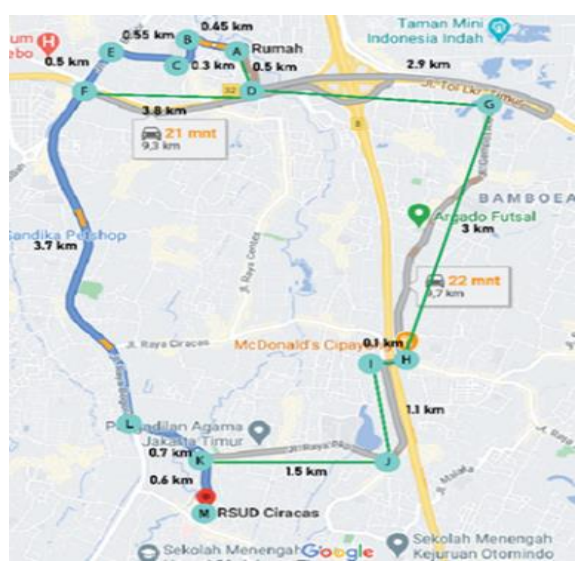

Gambar 3. Graf Node

Muhammad Taufiq Ismail, Copyright (C2021, MIB, Page 890 Submitted: 19/06/2021; Accepted: 08/07/2021; Published: 31/07/2021 


\section{JURNAL MEDIA INFORMATIKA BUDIDARMA}

Volume 5, Nomor 3, Juli 2021, Page 888-895

ISSN 2614-5278 (media cetak), ISSN 2548-8368 (media online)

Available Online at https://ejurnal.stmik-budidarma.ac.id/index.php/mib DOI 10.30865/mib.v5i3.3077

Pada gambar 3 merupakan graf node dari lokasi awal (rumah) menuju rumah RSUD Ciracas dimana setiap jarak antar node mempunyai nilai bobot yang berbeda-beda. Dimana jarak antar simpul digunakan untuk perhitungan yang menghasilnya jumlah nilai bobot.

\subsection{Penerapan Algoritma Dijkstra}

Pada tahap terakhir yaitu implementasi, dimana graf node pada gambar 2 di hitung dengan metode Algoritma Dijkstra yang nantinya di terapkan pada aplikasi C-Hos untuk menemukan rute terpendek. Berikut hasil perhitungan Algoritma Dijkstra bisa dilihat pada tabel 2.

Tabel 2. Tahap Perhitungan Algoritma Dijkstra

\begin{tabular}{|c|c|c|c|c|c|c|c|c|c|c|c|c|c|c|c|}
\hline Langkah & Simpul & Terkecil & A & $\mathrm{B}$ & $\mathrm{C}$ & $\mathrm{D}$ & $\mathrm{E}$ & $\mathrm{F}$ & $\mathrm{G}$ & $\mathrm{H}$ & I & $\mathrm{J}$ & K & $\mathrm{L}$ & $\mathrm{M}$ \\
\hline 1 & $\mathrm{~A}$ & 0 & $0 \mathrm{~A}$ & $0.45 \mathrm{~A}$ & $\infty$ & $0.5 \mathrm{~A}$ & $\infty$ & $\infty$ & $\infty$ & $\infty$ & $\infty$ & $\infty$ & $\infty$ & $\infty$ & $\infty$ \\
\hline 2 & B & $0.45 \mathrm{~A}$ & $0 \mathrm{~A}$ & $0.45 \mathrm{~A}$ & $0.75 \mathrm{~B}$ & $0.5 \mathrm{~A}$ & $\infty$ & $\infty$ & $\infty$ & $\infty$ & $\infty$ & $\infty$ & $\infty$ & $\infty$ & $\infty$ \\
\hline 3 & $\mathrm{C}$ & $0.75 \mathrm{~B}$ & $0 \mathrm{~A}$ & $0.45 \mathrm{~A}$ & $0.75 \mathrm{~B}$ & $0.5 \mathrm{~A}$ & $1.3 \mathrm{C}$ & $\infty$ & $\infty$ & $\infty$ & $\infty$ & $\infty$ & $\infty$ & $\infty$ & $\infty$ \\
\hline 4 & $\mathrm{E}$ & $1.3 \mathrm{C}$ & $0 \mathrm{~A}$ & $0.45 \mathrm{~A}$ & $0.75 \mathrm{~B}$ & $0.5 \mathrm{~A}$ & $1.3 \mathrm{C}$ & $1.8 \mathrm{E}$ & $\infty$ & $\infty$ & $\infty$ & $\infty$ & $\infty$ & $\infty$ & $\infty$ \\
\hline 5 & $\mathrm{~F}$ & $1.8 \mathrm{E}$ & $0 \mathrm{~A}$ & $0.45 \mathrm{~A}$ & $0.75 \mathrm{~B}$ & $0.5 \mathrm{~A}$ & $1.3 \mathrm{C}$ & $1.8 \mathrm{E}$ & $\infty$ & $\infty$ & $\infty$ & $\infty$ & $\infty$ & $5.5 \mathrm{~F}$ & $\infty$ \\
\hline 6 & $\mathrm{~L}$ & $5.5 \mathrm{~F}$ & $0 \mathrm{~A}$ & $0.45 \mathrm{~A}$ & $0.75 \mathrm{~B}$ & $0.5 \mathrm{~A}$ & $1.3 \mathrm{C}$ & $1.8 \mathrm{E}$ & $\infty$ & $\infty$ & $\infty$ & $\infty$ & $6.2 \mathrm{~L}$ & $5.5 \mathrm{~F}$ & $\infty$ \\
\hline 7 & $\mathrm{~K}$ & $6.2 \mathrm{~L}$ & $0 \mathrm{~A}$ & $0.45 \mathrm{~A}$ & $0.75 \mathrm{~B}$ & $0.5 \mathrm{~A}$ & $1.3 \mathrm{C}$ & $1.8 \mathrm{E}$ & $\infty$ & $\infty$ & $\infty$ & $\infty$ & $6.2 \mathrm{~L}$ & $5.5 \mathrm{~F}$ & $6.8 \mathrm{~K}$ \\
\hline 8 & M & $6.8 \mathrm{~K}$ & $0 \mathrm{~A}$ & $0.45 \mathrm{~A}$ & $0.75 \mathrm{~B}$ & $0.5 \mathrm{~A}$ & $1.3 \mathrm{C}$ & $1.8 \mathrm{E}$ & $\infty$ & $\infty$ & $\infty$ & $\infty$ & $6.2 \mathrm{~L}$ & $5.5 \mathrm{~F}$ & $6.8 \mathrm{~K}$ \\
\hline
\end{tabular}

Pada tabel 2 merupakan tahap perhitungan Algoritma Dijkstra, yang menghasil 8 langkah melalui beberapa node dan simpul hingga mendapatkan rute terpendek yaitu A-B-C-E-F-L-K dengan jumlah nilai $6.8 \mathrm{~km}$.

\subsection{Implementasi Program}

Tahap ini membahas tampilan aplikasi dan pengujian yang dilakukan dengan dua lokasi awal yang berbeda dengan 10 tujuan rumah sakit rujukan Covid-19.

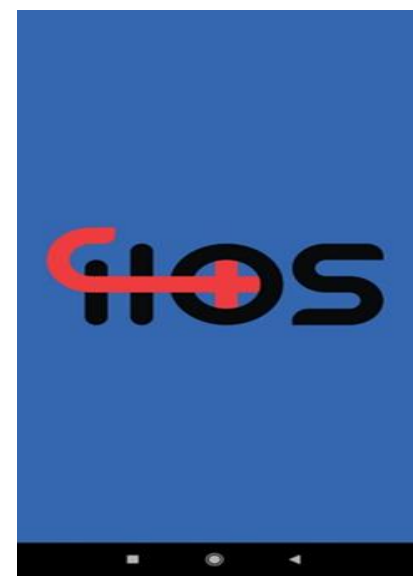

Gambar 2. Tampilan Splash Screen

Pada gambar 4 ialah tampilan splash screen dari aplikasi yang terdapat logo C-Hos.

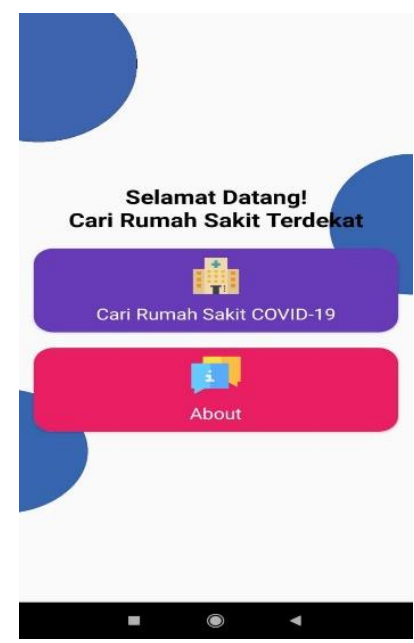

Gambar 3. Tampilan Awal

Muhammad Taufiq Ismail, Copyright (C2021, MIB, Page 891 
JURNAL MEDIA INFORMATIKA BUDIDARMA

Volume 5, Nomor 3, Juli 2021, Page 888-895

ISSN 2614-5278 (media cetak), ISSN 2548-8368 (media online)

Available Online at https://ejurnal.stmik-budidarma.ac.id/index.php/mib DOI 10.30865/mib.v5i3.3077

Pada gambar 5 ialah tampilan awal aplikasi C-Hos yang terdiri button Cari Rumah Sakit COVID-19 yang menampilkan menu rumah sakit rujukan Covid-19 dan About yang menampilkan informasi singkat tentang aplikasi C-Hos.

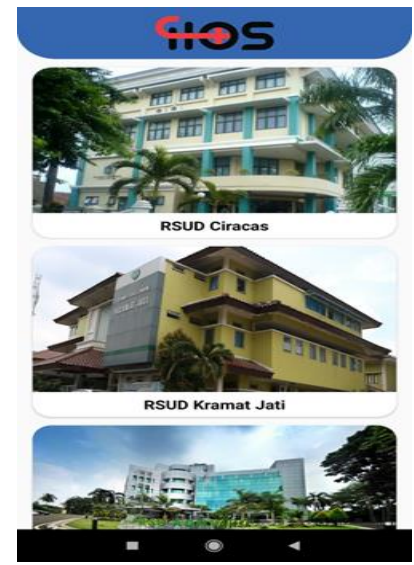

Gambar 4. Tampilan Menu Rumah Sakit Covid-19

Pada gambar 6 ialah tampilan menu rumah sakit Covid-19. Pada menu ini terdapat 10 pilihan rumah sakit rujukan Covid-19 dan logo aplikasi C-Hos.

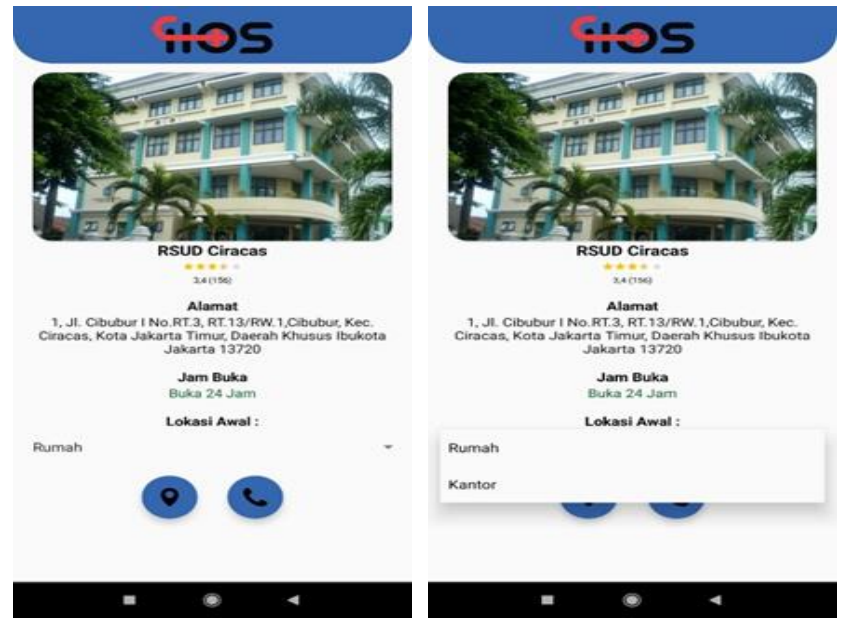

Gambar 5. Tampilan Menu Informasi Rumah Sakit Covid-19

Pada gambar 7 ialah tampilan menu informasi rumah sakit Covid-19 yang terdiri dari rating, alamat, jam buka, pilihan lokasi awal, button maps dan button contact. Pada lokasi awal sudah ditentukan terlebih dahulu, ada 2 lokasi awal yaitu rumah dan kantor. Lokasi awal rumah menggunakan alamat penulis (kordinat 6.302834678515513, 106.87641426329101) dan untuk kantor penulis menggunakan alamat PT Jasa Marga (Persero) (kordinat -6.290574261388371, 106.87867125031084). Pada button maps untuk menampilkan rute terpendek menuju rumah sakit sedangkan button contact untuk menampilkan no telephone rumah sakit.

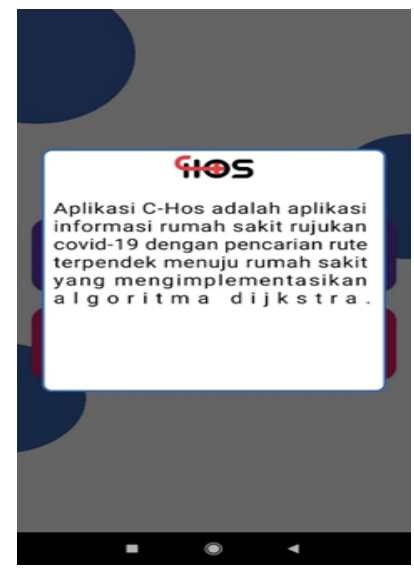

Gambar 6. Tampilan About

Muhammad Taufiq Ismail, Copyright (C2021, MIB, Page 892 Submitted: 19/06/2021; Accepted: 08/07/2021; Published: 31/07/2021 
JURNAL MEDIA INFORMATIKA BUDIDARMA

Volume 5, Nomor 3, Juli 2021, Page 888-895

ISSN 2614-5278 (media cetak), ISSN 2548-8368 (media online)

Available Online at https://ejurnal.stmik-budidarma.ac.id/index.php/mib DOI 10.30865/mib.v5i3.3077

\subsection{Pengujian Akurasi}

Hasil pengujian akurasi ini membandingkan langsung rute terpendek pada aplikasi C-Hos dengan rute sesunggunya yang terdapat terdapat di Google Maps. Berikut hasil penjabaran pengujian:

a. Rumah menuju RSUD Ciracas
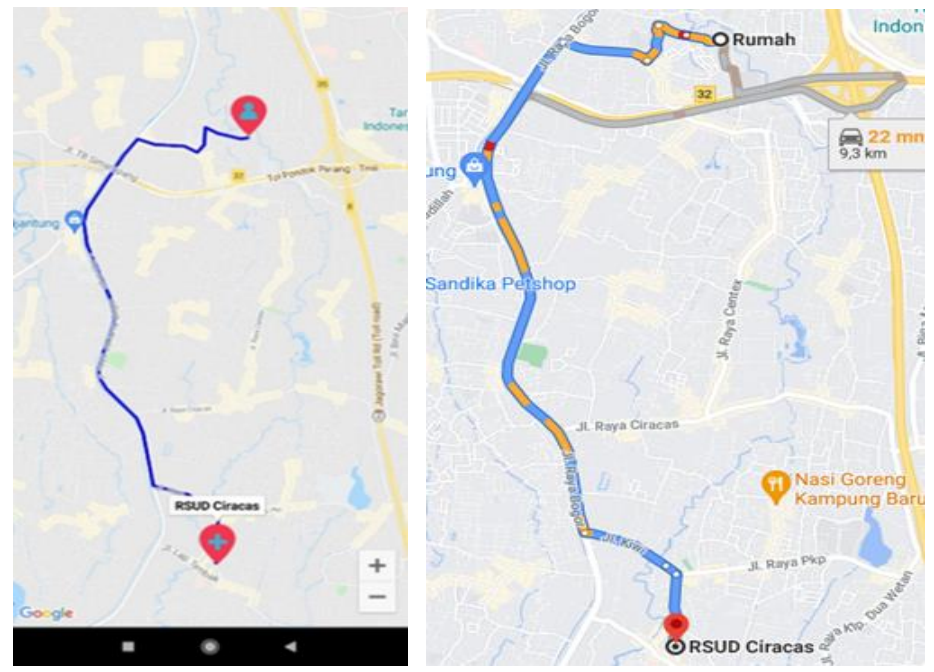

Gambar 7. Rute Rumah menuju RSUD Ciracas pada Aplikasi C-Hos dan Rute pada Google Maps

Pada gambar 9 menunjukan bahwa rute dari rumah menuju RSUD Ciracas pada aplikasi C-Hos ialah rute terpendek yang sesuai dengan rute yang sesungguhya pada Google Maps.

b. Kantor menuju RSUD Ciracas
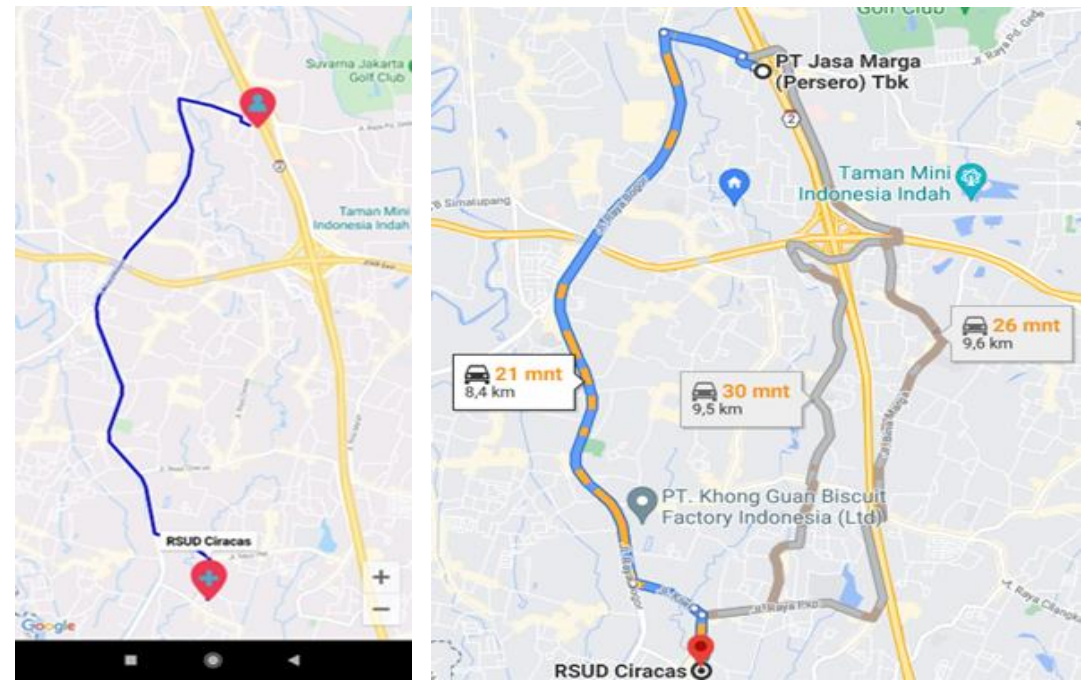

Gambar 8. Rute Rumah menuju RSUD Ciracas pada Aplikasi C-Hos dan Rute pada Google Maps

Pada gambar 10 menunjukan bahwa rute dari kantor menuju RSUD Ciracas pada aplikasi C-Hos ialah rute terpendek yang sesuai dengan rute yang sesungguhya pada Google Maps.

Table 3. Pengujian Akurasi

\begin{tabular}{cccc}
\hline No & Lokasi Awal & Lokasi Tujuan & Keterangan \\
\hline 1 & Rumah & RSUD Ciracas & Sesuai Rute pada Goole Maps \\
2 & Kantor & RSUD Kramat Jati & Sesuai Rute pada Goole Maps \\
3 & Rumah & Sesuai Rute pada Goole Maps \\
4 & Kantor & Sesuai Rute pada Goole Maps \\
5 & Rumah & Rumah Sakit Umum Adhyaksa & Sesuai Rute pada Goole Maps \\
6 & Kantor & RS Umum Bhayangkara Tk. I R. & Sesuai Rute pada Goole Maps \\
7 & Rumah & Said Sukanto & Sesuai Rute pada Goole Maps \\
8 & Kantor & Sesuai Rute pada Goole Maps \\
9 & Rumah & Rumah Sakit Harapan Bunda & Sesuai Rute pada Goole Maps
\end{tabular}

Muhammad Taufiq Ismail, Copyright (C2021, MIB, Page 893 
JURNAL MEDIA INFORMATIKA BUDIDARMA

Volume 5, Nomor 3, Juli 2021, Page 888-895

ISSN 2614-5278 (media cetak), ISSN 2548-8368 (media online)

Available Online at https://ejurnal.stmik-budidarma.ac.id/index.php/mib DOI 10.30865/mib.v5i3.3077

\begin{tabular}{cccc}
\hline No & Lokasi Awal & Lokasi Tujuan & Keterangan \\
\hline 11 & Rumah & Rumah Sakit Umum FK Uki & Sesuai Rute pada Goole Maps \\
12 & Kantor & & Sesuai Rute pada Goole Maps \\
13 & Rumah & Rumah Sakit Haji Jakarta & Sesuai Rute pada Goole Maps \\
14 & Kantor & & Sesuai Rute pada Goole Maps \\
15 & Rumah & Rumah Sakit Ridwan Meuraksa & Sesuai Rute pada Goole Maps \\
16 & Kantor & & Sesuai Rute pada Goole Maps \\
17 & Rumah & Rumah Sakit Pusat Nasional Otak & Sesuai Rute pada Goole Maps \\
18 & Kantor & & Sesuai Rute pada Goole Maps \\
19 & Rumah & RUSD Pasar Rebo & Sesuai Rute pada Goole Maps \\
20 & Kantor & Sesuai Rute pada Goole Maps \\
\hline
\end{tabular}

Berdasarkan tabel 3, diketahui pengujian dilakukan sebanyak 20 kali dengan lokasi awal yang berbeda yaitu rumah dan kantor dengan tujuan 10 rumah sakit dihasilkan 20 kali kesesuaian rute sesungguhnya pada Google Maps, maka dihasilkan akurasi sebagai berikut (1):

$$
\text { akurasi }=\frac{20-0}{20} * 100 \%=100 \%
$$

\section{KESIMPULAN}

Berdasarkan pembahasan dan pengujian aplikasi C-Hos ini dapat membantu masyarakat mengetahui rumah sakit mana saja yang menjadi rumah sakit rujukan covid-19 dan penerapan Algoritma Dijkstra pada aplikasi C-Hos sangat membantu dalam menentukan rute terpendek menuju rumah sakit rujukan Covid-19. Berdasarkan hasil dari pengujian sebanyak $20 \mathrm{kali}$, maka dihasilkan akurasi pada aplikasi ini sebesar $100 \%$. Pada penelitian ini terbatas pada lokasi awal yang diujikan, aplikasi C-Hos ini belum menggunakan current location pada lokasi awalnya. Untuk pengembangan aplikasi C-Hos ini dapat menggunakan current location pada lokasi awal agar aplikasi ini berjalan dengan maksimal.

\section{REFERENCES}

[1] M. B. T. Sampurno, T. C. Kusumandyoko, and M. A. Islam, "Budaya Media Sosial, Edukasi Masyarakat, dan Pandemi COVID-19,” SALAM J. Sos. dan Budaya Syar-i, vol. 7, no. 5, 2020, doi: 10.15408/sjsbs.v7i5.15210

[2] E. L. A. N. Ely Setyo Astuti, "Sig Pencarian Rute Terpendek Rumah Makan Halal Di Bali Dengan Menggunakan Metode Dijkstra," pp. 43-47, 2017.

[3] Raharjo, Muhammad Iksan, and Indah Susilawati, "Aplikasi Pencarian Rute Terdekat Wisata Kota Yogyakarta Menggunakan Algoritma Dijkstra Closest Route Search Application to Yogyakarta 's Tourism Spots Using the Dijkstra Algorithm," no. November, pp. 158-163, 2019

[4] J. Setiawan et al., "Penentuan Rute Terpendek Menuju Pusat Perbelanjaan Di Jakarta Menggunakan Algoritma Dijkstra," vol. 21, no. 3, pp. 156-165, 2019.

[5] J. Sauwani, V. N. Putra, and H. Agung, "Implementasi Algoritma Djikstra Untuk Menentukan Lokasi Dan Jarak Tempuh Terpendek Kampus It Di Jakarta,” J. Inform., vol. 6, no. 1, pp. 29-36, 2019, doi: 10.31311/ji.v6i1.4723.

[6] M. S. Yusuf, H. M. Az-zahra, and D. H. Apriyanti, "Implementasi Algoritma Dijkstra Dalam Menemukan Jarak Terdeka Dari Lokasi Pengguna Ke Tanaman Yang Di Tuju Berbasis Android ( Studi Kasus di Kebun Raya Purwodadi ), J. Pengemb. Teknol. Inf. dan Ilmu Komput., vol. 1, no. 12, pp. 1779-1781, 2017.

[7] L. Tommy and Y. S. Japriadi, "Implementasi Algoritma Dijkstra pada Aplikasi Pencarian Jalur Terpendek Lokasi SPBU di Pangkalpinang Berbasis Android,” Konf. Nas. Sist. Inf., pp. 1018-1023, 2018.

[8] Y. Anshori, Y. Y. Joefrie, J. T. Informasi, F. Teknik, and U. Tadulako, "IMPLEMENTASI ALGORITMA DIJKSTRA DALAM Implementation of Dijkstra Algorithm in Creating Pesona Palu Application," vol. 1, no. 1, pp. 25-31, 2018.

[9] E. C. Galih and R. A. Krisdiawan, "Implementasi Algoritma Dijkstra Pada Aplikasi Wisata Kuningan Berbasis Android," Nuansa Inform., vol. 12, no. 1, 2018, doi: 10.25134/nuansa.v12i1.1344.

[10] B. Folaiman, R. Rosihan, and A. Mubarak, "Implementasi Algoritma Dijkstra Untuk Penentuan Jalur Terpendek Pada Aplikasi Evakuasi Bencana Untuk Penyandang Disabilitas,” JIKO (Jurnal Inform. dan Komputer), vol. 1, no. 2, pp. 6169, 2018, doi: 10.33387/jiko.v1i2.770.

[11] I. Mahesa and F. T. Industri, "Penerapan algortima dikstra pada rancang bangun lokasi rental alat outdoor di kota malang berbasis android," vol. 2, no. 2, pp. 122-128, 2018.

[12] J. V. Ginting and E. S. Barus, "Aplikasi Penentuan Rute Rumah Sakit Terdekat Menggunakan Algoritma Dijkstra," J. Mantik Penusa, vol. 2, no. 2, pp. 1-8, 2018.

[13] Y. Anshori, A. Y. E. Dodu, and F. Kurniawan, "Perancangan Robot Penelusur Menggunakan Algoritma Dijkstra dan Metode Maze Solver," Techno.Com, vol. 18, no. 2, pp. 166-177, 2019, doi: 10.33633/tc.v18i2.2335.

[14] N. A. Sudibyo, P. E. K. A. Setyawan, Y. P. Surya, and R. Hidayat, "Implementasi Algoritma Dijkstra dalam Pencarian Rute Terpendek Tempat Wisata di Kabupaten Klaten," vol. 2, no. 1, pp. 1-9, 2020.

[15] M. K. Harahap and N. Khairina, "Pencarian Jalur Terpendek dengan Algoritma Dijkstra," SinkrOn, vol. 2, no. 2, p. 18, 2017, doi: 10.33395/sinkron.v2i2.61.

[16] B. Kristaung and K. Handoko, "Penentuan Jarak Terdekat Wisata Kuliner Menggunakan Algoritma Di Jkstra," vol. 01, pp. 53-61, 2021 
JURNAL MEDIA INFORMATIKA BUDIDARMA

Volume 5, Nomor 3, Juli 2021, Page 888-895

ISSN 2614-5278 (media cetak), ISSN 2548-8368 (media online)

Available Online at https://ejurnal.stmik-budidarma.ac.id/index.php/mib DOI 10.30865/mib.v5i3.3077

[17] Tim Komunikasi Komite Penanganan Corona Virus Disease 2019 (Covid-19) dan Pemulihan Ekonomi Nasional. (2021, Jun.12) Pasien Sembuh Terus Meningkat Menjadi 1.740.436 Orang [online].Available https://covid19.go.id/p/berita/pasien-sembuh-terus-meningkat-menjadi-1740436-orang. 